\title{
Kisspeptin signalling and its roles in humans
}

Eng Loon Tng, MBBS, MRCP

\begin{abstract}
Kisspeptins are a group of peptide fragments encoded by the KISS1 gene in humans. They bind to kisspeptin receptors with equal efficacy. Kisspeptins and their receptors are expressed by neurons in the arcuate and anteroventral periventricular nuclei of the hypothalamus. Oestrogen mediates negative feedback of gonadotrophin-releasing hormone secretion via the arcuate nucleus. Conversely, it exerts positive feedback via the anteroventral periventricular nucleus. The sexual dimorphism of these nuclei accounts for the differential behaviour of the hypothalamic-pituitary-gonadal axis between genders. Kisspeptins are essential for reproductive function. Puberty is regulated by the maturation of kisspeptin neurons and by interactions between kisspeptins and leptin. Hence, kisspeptins have potential diagnostic and therapeutic applications. Kisspeptin agonists may be used to localise lesions in cases of hypothalamic-pituitary-gonadal axis dysfunction and evaluate the gonadotrophic potential of subfertile individuals. Kisspeptin antagonists may be useful as contraceptives in women, through the prevention of premature luteinisation during in vitro fertilisation, and in the treatment of sex steroid-dependent diseases and metastatic cancers.
\end{abstract}

Keywords: hypothalamic-pituitary-gonadal axis, kisspeptins

\section{INTRODUCTION}

This review uses the nomenclature proposed by Gottsch et al to describe the kisspeptin signalling system. KISS1 and Kiss 1 refer to the human and non-human genes for kisspeptins, while KISS1R and Kiss1 $r$ refer to the human and non-human receptors, respectively. The gene products of KISS 1 and Kiss 1 are collectively known as kisspeptins. ${ }^{(1)}$

The KISS1/KisS 1 gene encodes the kisspeptin precursor, a peptide comprising 145 amino acids. ${ }^{(2)}$ This is proteolysed to fragments of various lengths. ${ }^{(3-5)}$ Kisspeptin-54, comprising 54 amino acids, is the major fragment, ${ }^{(5)}$ while other fragments include kisspeptin-10, kisspeptin-13 and kisspeptin-14. (Fig. 1) These fragments share an RFamide motif at the carboxy terminal. ${ }^{(3-5)}$ Kisspeptins are expressed in the hypothalamus, gonads, placenta, liver and pancreas, ${ }^{(3-6)}$ and bind to KISS1R/Kiss1 $r$ with equal efficacy. ${ }^{(3)}$

Kiss1 $\mathrm{r}$ was discovered as an orphan receptor in the rat brain. It is a G-protein coupled receptor (GPCR) with homology to galanin receptors. ${ }^{(6)} \mathrm{KISS} 1 \mathrm{R}$ was discovered later, and was variably termed GPR54, AXOR12, hOT7T175 and HH8. ${ }^{(3-5)}$ KISS1R/Kiss1r was subsequently recognised as the endogenous kisspeptin receptor. It is expressed in the hypothalamus, pituitary gland, gonad, placenta, pancreas and kidney. ${ }^{(3,4,6-10)}$

\section{INTRACELLULAR SIGNALLING MECHANISMS}

KISS1R/Kiss1 $r$ is a GPCR coupled to the $G$ protein subunit, $G_{q / 11} \alpha^{(3,4)}$ Ligand binding activates phospholipase $\mathrm{C}(\mathrm{PLC})$, leading to the hydrolysis of phosphatidyl inositol bisphosphate and the formation of diacylglycerol (DAG). DAG then activates protein kinase C. Mitogen-activated protein kinases (MAPKs) are phosphorylated, thereby activating $\beta$-arrestin and inositol-1,4,5-triphosphate. Consequently, intracellular calcium is released, depolarising the neuron $^{(3,4,11-15)}$ (Fig. 2). PLC-independent mechanisms may also

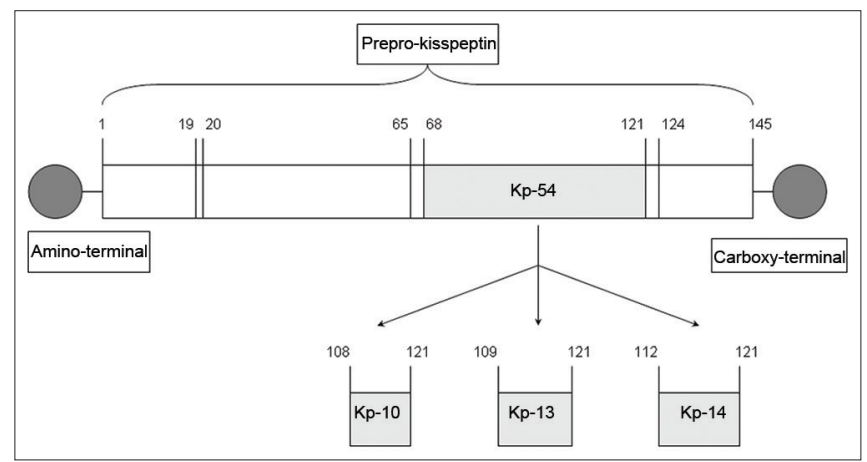

Fig. 1 Diagram shows the structure of a kisspeptin (Kp) protein.

increase the intracellular calcium level; these include the opening of inwardly rectifying potassium channels and non-selective cation channels. ${ }^{(13,16)}$ Kisspeptin neurons form synapses with gonadotrophin-releasing hormone $(\mathrm{GnRH})$ expressing neurons. Depolarisation of kisspeptin neurons leads to the depolarisation of $\mathrm{GnRH}$ neurons, and subsequent modulation of luteinising hormone (LH) and follicle-stimulating hormone (FSH) release.

KISS1R/Kiss1r is desensitised with continuous kisspeptin exposure. In animals, intermittent kisspeptin administration was found to raise LH levels. However, LH was suppressed after continuous administration of kisspeptin, as it induced long-lasting depolarisation in $\mathrm{GnRH}$ neurons, followed by desensitisation..$^{(7,9,13,16-24)}$ Such desensitisation is not due to $\mathrm{GnRH}$ depletion, ${ }^{(7,17)}$ but may be due to clathrin-mediated internalisation of arrestin and KISS1R in internalised vesicles after kisspeptin activation. $^{(15)}$

\section{Cotransmitters of kisspeptin signalling}

Neurokinin B (NKB) and dynorphin (Dyn) are cotransmitters of kisspeptin signalling. NKB is a tachykinin peptide that binds to the receptor NK3R. ${ }^{(25)}$ In humans, NKB is called TAC3 and binds 


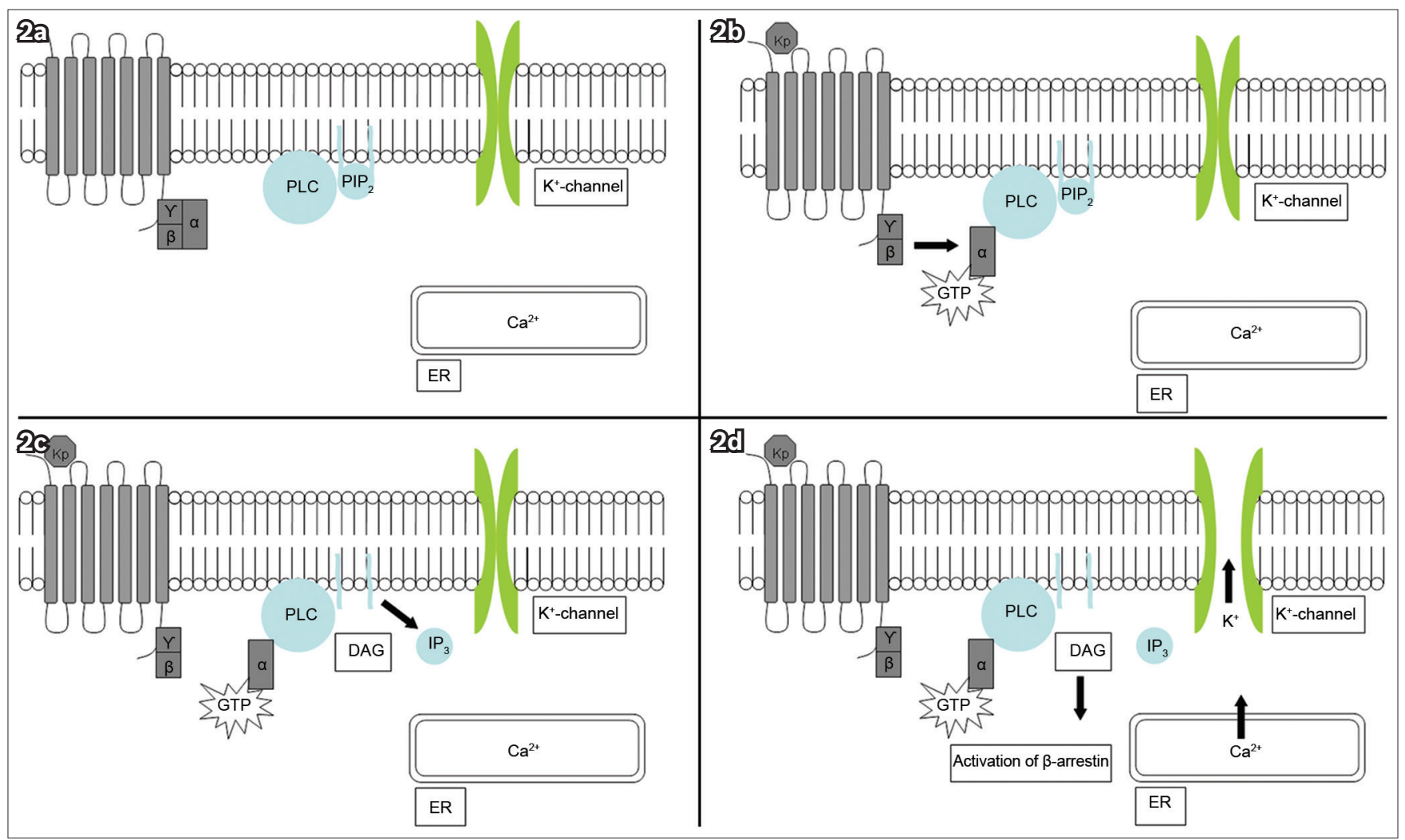

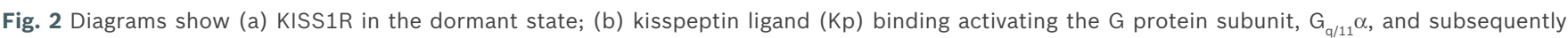
phospholipase C (PLC); (c) PLC activation leading to the formation of inositol-1,4,5-triphosphate (IP3) and diacylglycerol (DAG); and (d) IP3 causing the release of intracellular calcium $\left(\mathrm{Ca}^{2+}\right)$ from the endoplasmic reticulum (ER). PLC-independent mechanisms open the potassium ( $\left.\mathrm{K}^{+}\right)$channels. These events depolarise the kisspeptin neuron. ${ }^{(26)}$ GTP: guanosine triphosphate; PIP2: phosphatidyl inositol bisphosphate (Adapted from Pinilla et al)

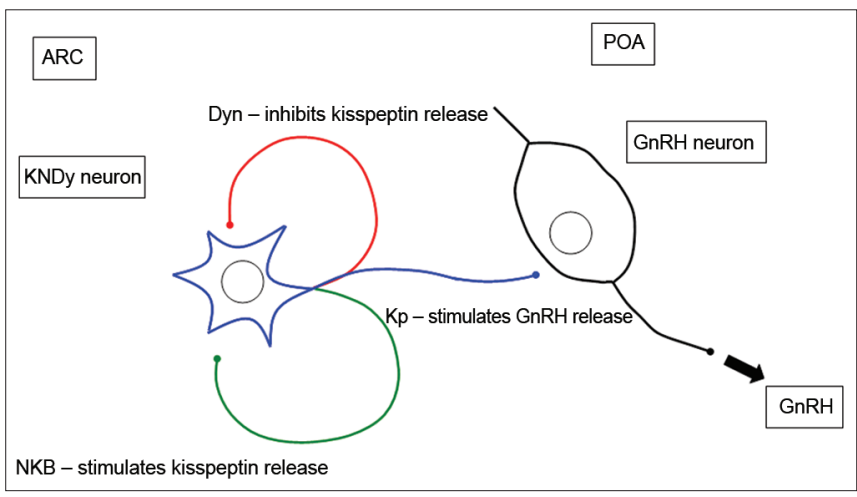

Fig. 3 Diagram shows cotransmitters of kisspeptin (Kp) signalling. Dynorphin (Dyn) inhibits and neurokinin B (NKB) stimulates Kp release by Kp/NKB/Dyn (KNDy) neurons. ${ }^{(25)}$ ARC: arcuate nucleus; $\mathrm{GnRH}$ : gonadotrophin-releasing hormone; POA: preoptic area (Adapted from Pinilla et al)(26)

to the receptor TACR3. ${ }^{(27)}$ Dyn is an endogenous opioid peptide that binds to the kappa opioid receptor. ${ }^{(28)}$ NKB is an excitatory stimulus, ${ }^{(29-32)}$ while Dyn is an inhibitory stimulus to kisspeptin release in the hypothalamus (Fig. 3). ${ }^{(28,30,33)}$ Evidence of NKB and Dyn as cotransmitters includes the colocalisation of Kiss 1, NKB and Dyn in the neurons of animal hypothalami. ${ }^{(34-36)}$ These neurons are termed kisspeptin/NKB/Dyn (KNDy) neurons and project to $\mathrm{GnRH}$ neurons in animals, ${ }^{(34)}$ in keeping with the role of kisspeptins in modulating GnRH release (Fig. 3). Similarly, NK3Rs are found in the hypothalami and GnRH neurons of animals. ${ }^{(37-39)}$ Importantly, NK3R agonists activated Kiss 1 neurons and increased LH secretion in rats. This observation was, however, absent in Kiss1 $\mathrm{r}$ knockout mice, ${ }^{(29-31)}$ suggesting that NKB is upstream of Kiss1 $r$ in the signalling pathway. ${ }^{(32)}$ In addition, inactivating mutations of TAC3 and TACR3 cause hypogonadotrophic hypogonadism $(\mathrm{HH}) .^{(27)}$ Dyn was also found to inhibit LH secretion in animals..$^{(28,30,33)}$

\section{Neuroanatomy of the kisspeptin signalling system}

Kisspeptins and their receptors are localised to various parts of the nervous system. The location of kisspeptin neurons differs between animal species. In humans, kisspeptin neurons were identified in the hypothalamus, basal ganglia and periventricular region, while KISS1R was localised to the hypothalamus, basal ganglia, amygdala, substantia nigra, hippocampus and spinal cord. . $^{(4,5,36)}$ In rodents, kisspeptin neurons were demonstrated in various parts of the hypothalamus, including the arcuate nucleus (ARC) and the anteroventral periventricular nucleus (AVPV); ${ }^{(40-45)}$ kisspeptin neurons in the AVPV formed the major afferent neurons to $\mathrm{GnRH}$ neurons. ${ }^{(42)}$ In sheep hypothalami, kisspeptins were detected in the preoptic area (POA) and the ARC, ${ }^{(46-48)}$ with the kisspeptin neurons in the POA forming the major afferent neurons to GnRH neurons. ${ }^{(47)}$

\section{REPRODUCTIVE ROLE Regulation of GnRH}

Kisspeptin neurons are located in the posterior part of the ARC, which is the putative $\mathrm{GnRH}$ pulse generator in primates. ${ }^{(49)}$ Administration of kisspeptin antagonists in this region suppresses GnRH pulsatility in animals, ${ }^{(50,51)}$ suggesting that kisspeptin neurons form the $\mathrm{GnRH}$ pulse generator. Kisspeptins stimulate GnRH secretion by 

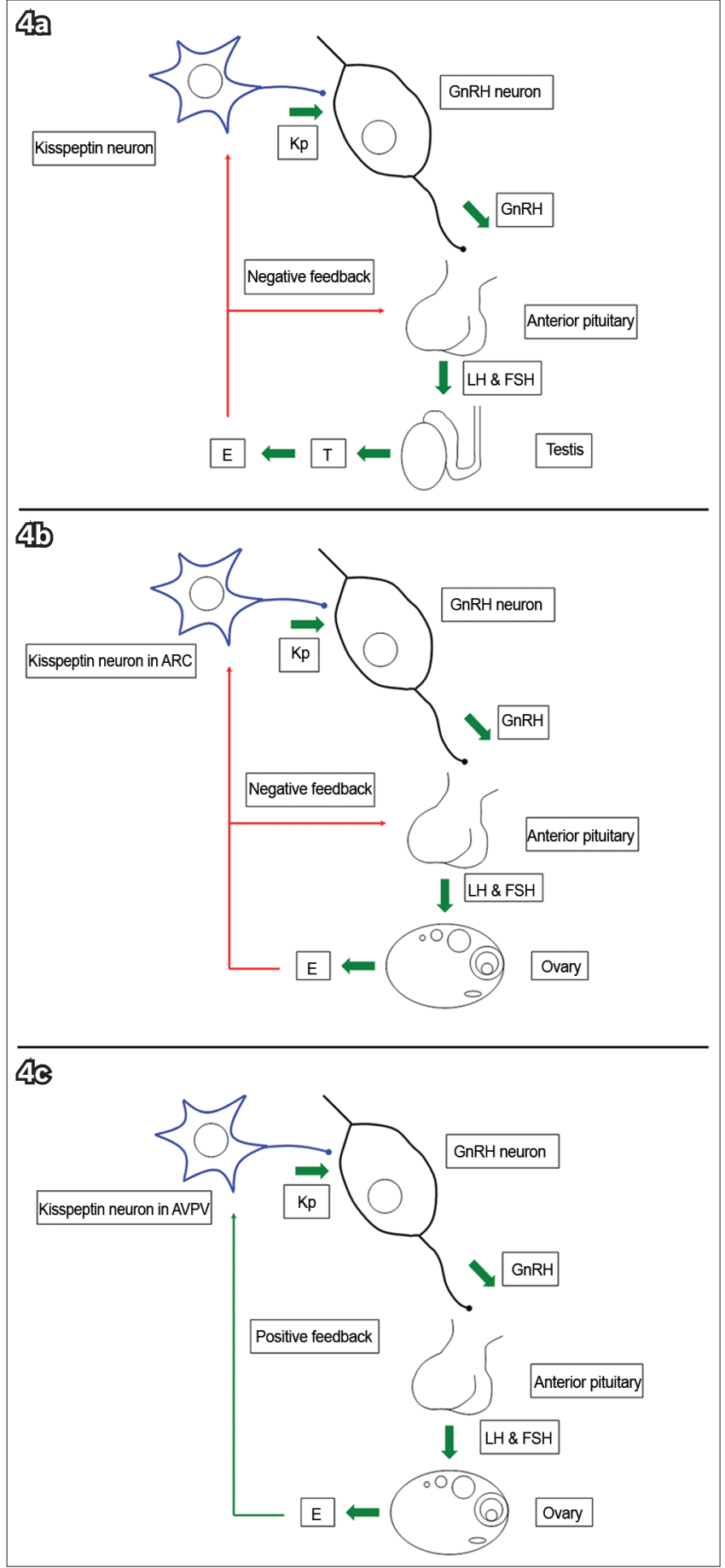

Fig. 4 The diagram shows that (a) kisspeptin (Kp) stimulates gonadotrophinreleasing hormone $(\mathrm{GnRH})$ secretion and subsequently gonadotrophin release. Testosterone $(\mathrm{T})$ is aromatised to oestrogen $(\mathrm{E})$, which exerts negative feedback on the anterior pituitary gland and hypothalamus. (b) E exerts negative feedback on $\mathrm{GnRH}$ via Kp neurons in the arcuate nucleus (ARC). (c) E exerts positive feedback on GnRH via Kp neurons in the anteroventral periventricular nucleus (AVPV). ${ }^{(25)} \mathrm{FSH}$ : follicle-stimulating hormone; LH: luteinising hormone (Adapted from Pinilla et al) ${ }^{(26)}$

GnRH neurons. This effect was observed with both central and systemic administration of kisspeptins. ${ }^{(52-58)}$ Human studies showed kisspeptin-induced LH release in women. ${ }^{(59)}$ In animals, GnRH and LH levels are elevated by kisspeptins. ${ }^{(7,52,54,58,60-62)}$ Kisspeptins also induced C-fos expression (marker of cellular activation) in rodent $\mathrm{GnRH}$ neurons ${ }^{(8,54)}$ and evoked depolarisation of $\mathrm{GnRH}$ neurons in electrophysiological studies. ${ }^{(9,13,16,19,20)}$ Moreover, the stimulatory effect of kisspeptins can be blocked by GnRH antagonists. ${ }^{(53,54,60,62,63)}$ Human subjects with KISS1R mutations and $\mathrm{HH}$ responded to $\mathrm{GnRH}$, while mice with Kiss1r mutations preserved hypothalamic GnRH content. ${ }^{(64)}$ Collectively, these observations affirm that kisspeptins are excitatory stimuli located upstream of $\mathrm{GnRH}$ in the hypothalamic-pituitary-gonadal (HPG) axis.

It is unclear whether kisspeptins directly regulate pituitary function. In contrast to its effect on $\mathrm{LH}$ secretion, the $\mathrm{FSH}$ response to kisspeptin is comparatively delayed and less robust in humans and rats. ${ }^{(59,63,65)}$ This may be due to differences in secretory patterns of the gonadotrophins, ${ }^{(66)}$ different gonadotroph responses to kisspeptins ${ }^{(65,67)}$ or different feedback signals to the gonadotrophs (e.g. inhibin). ${ }^{(68,69)}$

\section{Sexual dimorphism}

Kisspeptin neurons are located in two main regions of the hypothalamus. The first region is the ARC in rodents ${ }^{(44,45,70)}$ or its equivalent, the infundibular nucleus, in primates. ${ }^{(71-73)}$ This group of neurons mediates oestrogen-induced negative feedback on the HPG axis. ${ }^{(49,72,73)}$ The second region is the AVPV in rodents, or the equivalent POA in sheep and primates. ${ }^{(25,36,74)}$ This group of neurons mediates positive feedback from oestrogen ${ }^{(75-78)}$ (Fig. 4). AVPV neurons behave differently between the genders. Only female AVPV neurons, which are also larger and more numerous, ${ }^{(43,70)}$ demonstrate the $\mathrm{LH}$ surge in response to oestrogen. ${ }^{(79-83)}$ Similarly, oestrogen increases Kiss 1 mRNA and kisspeptin levels in rodent AVPV. ${ }^{(44,45)}$

Sex steroid exposure in utero may determine the behaviour of the kisspeptin system and HPG axis after sexual maturation. In rats, neonatal exposure to oestrogenic compounds suppressed kisspeptin production in the peripubertal and adult stages. ${ }^{(52,84,85)}$ This resulted in $\mathrm{HH}$, which resolved with exogenous kisspeptin. In neonatal female rats, exposure to androgenic compounds led to reduced kisspeptin production by the AVPV during adulthood. This was not reversible with exogenous oestrogen. ${ }^{(70)}$ Thus, early androgen exposure led to androgenisation of the AVPV. Conversely, gonadectomised neonatal male rats had increased kisspeptin production in the AVPV during adulthood. These rats demonstrated the LH surge with exogenous oestrogen, indicating feminisation of the AVPV. ${ }^{(86)}$

\section{Negative feedback regulation}

Oestrogen and testosterone exert negative feedback on $\mathrm{GnRH}$ release (Fig. 4b), which is mediated via oestrogen receptor $\alpha$ $(E R \alpha){ }^{(44,45,52)}$ Testosterone is aromatised to oestrogen prior to receptor binding ${ }^{(45,87)}$ (Fig. 4). However, GnRH neurons do not express $E R \alpha$, while kisspeptin neurons do. ${ }^{(44,45,71,75,88)}$ Hence, it is likely that oestrogen binds to ER $\alpha$ on kisspeptin neurons in the ARC or infundibular nucleus, inhibiting kisspeptin and subsequently GnRH release. ${ }^{(44)}$ Several lines of evidence support this hypothesis. In gonadectomised animals and humans, sex steroid levels declined, while kisspeptins, GnRH and gonadotrophin levels increased. . $8,44,45,52,71,72,89,90)$ However, antagonism of Kiss1 $r$ in rodents prevented the rise of gonadotrophins. ${ }^{(31,50,91,92)}$ Notably, 
the elevated kisspeptin levels were localised to the ARC or infundibular nucleus. ${ }^{(44,45,52,71,73,87)}$ Gonadectomised Kiss1 $\mathrm{r}$ and Kiss 1 knockout mice demonstrated similar behaviour. ${ }^{(31,91,92)}$ Kisspeptin production in the ARC was shown to be reduced by sex steroid administration in animal studies. ${ }^{(44,52,70,87)}$

\section{Positive feedback regulation}

Oestrogen exerts positive feedback on kisspeptin neurons in the AVPV in animals. This effect is also mediated via $\mathrm{ER} \alpha^{(44,45,93,94)}$ and may account for the LH surge in the menstrual cycle. The evidence supporting this includes the fall in kisspeptin level in gonadectomised animals, which was more pronounced in females. ${ }^{(44,45)}$ Secondly, AVPV kisspeptin levels rose prior to the LH surge in animals; ${ }^{(41,95)}$ pharmacologic studies confirmed that the LH surge was induced by kisspeptins. ${ }^{(96-98)}$ Furthermore, LH levels increased with kisspeptin administration in women ${ }^{(99)}$ and central infusion of kisspeptin antagonists blocked the LH surge in animals. ${ }^{(100,101)}$ Thirdly, lesions in the AVPV prevented the LH surge, while oestrogen administration to the AVPV caused it. ${ }^{(96,102-105)}$ Lastly, blockage of ER $\alpha$ prevented the LH surge in animals. ${ }^{(44,45,93,94)}$

\section{Reproductive function and puberty}

Kisspeptins assume a key role in reproduction. $\mathrm{HH}$ occurs in humans and mice with defective KISS1R and Kiss1r. ${ }^{(7,106-109)}$ Notably, kisspeptins regulate the HPG axis by binding to Kiss1 $\mathrm{r}$ in the hypothalamus, as evidenced by the failure of kisspeptins to increase $\mathrm{LH}$ or $\mathrm{C}$-fos in the GnRH neurons of Kiss1 $\mathrm{r}$ knockout mice. $^{(7,110)}$

The maturation of kisspeptin neurons may be responsible for puberty, as suggested by the following. Firstly, inactivating mutations in KISS1R/Kiss1r, ${ }^{(106-108)}$ and KISS1/Kiss 164,111) led to $\mathrm{HH}$ and pubertal failure. Secondly, animal studies demonstrated an increase in Kiss1 and Kiss1r in the AVPV and/or ARC at puberty; ${ }^{(9,43,52,62,112-117)}$ more kisspeptin neurons also project to GnRH neurons. ${ }^{(43,118-120)}$ Thirdly, GnRH response to kisspeptins increases after puberty, which is secondary to improved signalling efficiency rather than increased receptor density ${ }^{(9)}$ (Fig. 5). Finally, exogenous kisspeptins induced precocious puberty in rodents and monkeys, ${ }^{(9,54,62,121)}$ and stimulated a GnRH secretion pattern resembling puberty, ${ }^{(22,122)}$ while kisspeptin antagonists delayed puberty in these animals. ${ }^{(122,123)}$

\section{Kisspeptins and energy homeostasis}

Energy homeostasis and the reproductive system are linked, as exemplified by $\mathrm{HH}$ occurring in energy-deficient states. Energydeprived rats and sheep had reduced Kiss1 mRNA in their hypothalami, reduced LH levels and pubertal arrest. ${ }^{(47,124-131)}$ With kisspeptin administration, puberty resumed, while gonadotrophin and androgen levels normalised. ${ }^{(57,124,125)}$ Interactions between kisspeptins and leptin may account for these observations. This postulation is supported by the finding that leptin activates $\mathrm{GnRH}$ neurons. ${ }^{(132)}$ However, GnRH neurons lack leptin receptors, while kisspeptin neurons in the ARC express the leptin receptor gene. ${ }^{(47,133,134)}$ Additionally, leptin-deficient rats have reduced Kiss 1 mRNA in their ARC. ${ }^{(133,135)}$ Leptin administration increased

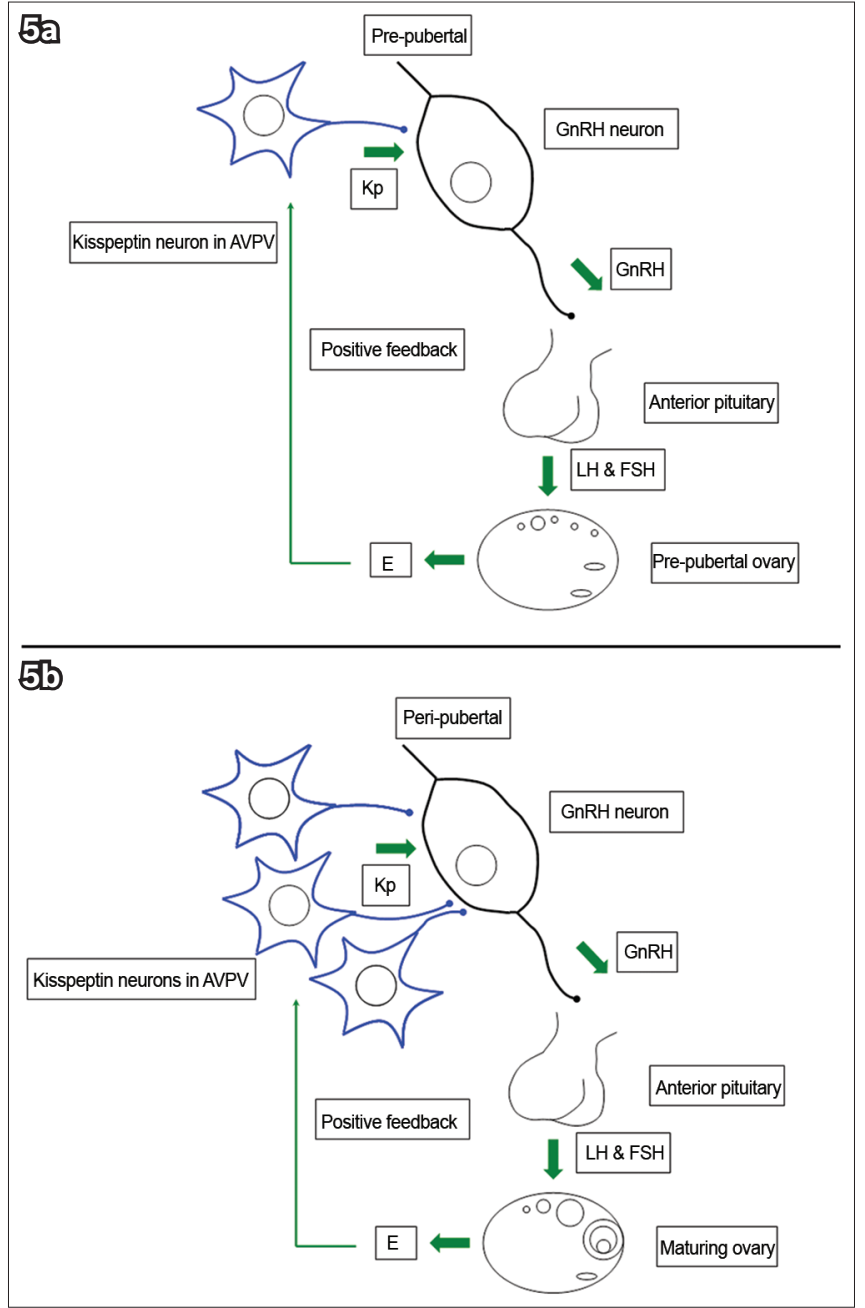

Fig. 5 Diagrams show (a) kisspeptin $(\mathrm{Kp})$ and gonadotrophin-releasing hormone $(\mathrm{GnRH})$ neurons in the prepubertal phase; and (b) increased neuron density and signalling efficiency in the peripubertal phase. ${ }^{(25)}$ AVPV: anteroventral periventricular nucleus; $\mathrm{E}$ : oestrogen; $\mathrm{FSH}$ : follicle-stimulating hormone; LH: luteinising hormone (Adapted from Pinilla et al)(26)

hypothalamic Kiss $1 \mathrm{mRNA}$ in fasted rats ${ }^{(125)}$ and cell models. ${ }^{(129,136)}$ It also depolarised kisspeptin neurons in the ARC of rats. ${ }^{(137)}$ Therefore, it is likely that leptin activates GnRH neurons via stimulation of kisspeptin neurons in the ARC.

\section{OTHER ROLES}

Kisspeptin was initially discovered in 1996 as a metastasis suppressor ${ }^{(138)}$ and was named metastin. ${ }^{(138,139)}$ Over the last two decades, increasing evidence confirmed its unique role. Kisspeptins suppress metastasis by restricting the growth of the secondary tumour. ${ }^{(140)}$ Binding of kisspeptin to KISS1R/Kiss1 $r$ increases intracellular calcium and activation of MAPKs, which limits cell motility and proliferation. ${ }^{(141)}$ Kisspeptins have been investigated as potential treatment targets for melanoma, ${ }^{(142)}$ thyroid cancer, ${ }^{(11)}$ bladder cancer, ${ }^{(143)}$ squamous cell carcinoma of the oesophagus, ${ }^{(144)}$ gastric cancer, ${ }^{(145)}$ hepatocellular carcinoma ${ }^{(146)}$ and breast cancer. ${ }^{(138,147)}$ Further studies may provide positive insights in this field.

\section{POTENTIAL CLINICAL APPLICATIONS}

Kisspeptin agonists and antagonists have potential diagnostic and therapeutic applications. Kisspeptin agonists may localise 
lesions in HPG axis dysfunction and can be used to evaluate the gonadotrophic potential of infertile individuals. They may also be used to treat subjects with subfertility through the stimulation of LH to result in ovulation. Kisspeptin antagonists may reveal the role of kisspeptins in various physiological and pathological states of the HPG axis. ${ }^{(25)}$ As they reduce LH pulse frequency and amplitude without affecting basal LH secretion, kisspeptin antagonists may be useful as contraceptives in women or in the treatment of sex steroid-dependent diseases, such as prostate and breast cancer, endometriosis and uterine fibroids. ${ }^{(50,100)}$ Furthermore, they may prevent premature luteinisation during in vitro fertilisation. ${ }^{(148,149)}$ Lastly, kisspeptins may be used in the treatment of metastatic cancers.

\section{CONCLUSION}

Kisspeptins play essential roles in reproduction. They are involved in in utero sexual development and determine the onset of puberty. More importantly, they may be the link between energy homeostasis and the reproductive system. After sexual maturation, kisspeptins regulate HPG axis function by modulating gonadotrophin release. The difference in kisspeptin neuroanatomy accounts for sexual dimorphism of the HPG axis between genders. Potential clinical uses of kisspeptins include the treatment of delayed or precocious puberty, subfertility, downregulation of sex steroids in the treatment of sex steroid-dependent tumours, contraception and the treatment of metastatic cancers.

\section{REFERENCES}

1. Gottsch ML, Clifton DK, Steiner RA. From KISS1 to kisspeptins: An historical perspective and suggested nomenclature. Peptides 2009; 30:4-9.

2. West A, Vojta PJ, Welch DR, Weissman BE. Chromosome localization and genomic structure of the KiSS-1 metastasis suppressor gene (KISS1). Genomics 1998; 54:145-8.

3. Kotani M, Detheux M, Vandenbogaerde A, et al. The metastasis suppressor gene KiSS-1 encodes kisspeptins, the natural ligands of the orphan G protein-coupled receptor GPR54. J Biol Chem 2001; 276:34631-6.

4. Muir Al, Chamberlain L, Elshourbagy NA, et al. AXOR12, a novel human G protein-coupled receptor, activated by the peptide KiSS-1. J Biol Chem $2001 ; 276: 28969-75$.

5. Ohtaki T, Shintani Y, Honda S, et al. Metastasis suppressor gene KiSS-1 encodes peptide ligand of a G-protein-coupled receptor. Nature 2001; 411:613-7.

6. Lee DK, Nguyen T, O'Neill GP, et al. Discovery of a receptor related to the galanin receptors. FEBS Lett 1999; 446:103-7.

7. Messager S, Chatzidaki EE, Ma D, et al. Kisspeptin directly stimulates gonadotropin-releasing hormone release via $\mathrm{G}$ protein-coupled receptor 54. Proc Natl Acad Sci U S A 2005; 102:1761-6.

8. Irwig MS, Fraley GS, Smith JT, et al. Kisspeptin activation of gonadotropin releasing hormone neurons and regulation of KiSS-1 mRNA in the male rat. Neuroendocrinology 2004; 80:264-72.

9. Han SK, Gottsch ML, Lee KJ, et al. Activation of gonadotropin-releasing hormone neurons by kisspeptin as a neuroendocrine switch for the onset of puberty. J Neurosci 2005; 25:11349-56.

10. Parhar IS, Ogawa S, Sakuma Y. Laser-captured single digoxigenin-labeled neurons of gonadotropin-releasing hormone types reveal a novel $\mathrm{G}$ proteincoupled receptor (Gpr54) during maturation in cichlid fish. Endocrinology 2004; 145:3613-8.

11. Ringel MD, Hardy E, Bernet VJ, et al. Metastin receptor is overexpressed in papillary thyroid cancer and activates MAP kinase in thyroid cancer cells. J Clin Endocrinol Metab 2002; 87:2399.

12. Castellano JM, Navarro VM, Fernández-Fernández R, et al. Ontogeny and mechanisms of action for the stimulatory effect of kisspeptin on gonadotropin-releasing hormone system of the rat. Mol Cell Endocrinol 2006; 257-258:75-83.

13. Liu X, Lee K, Herbison AE. Kisspeptin excites gonadotropin-releasing hormone neurons through a phospholipase C/calcium-dependent pathway regulating multiple ion channels. Endocrinology 2008; 149:4605-14.

14. Stafford LJ, Xia C, Ma W, Cai Y, Liu M. Identification and characterization of mouse metastasis-suppressor KiSS1 and its G-protein-coupled receptor. Cancer Res 2002; 62:5399-404.

15. Pampillo M, Camuso N, Taylor JE, et al. Regulation of GPR54 signaling by GRK2 and \{beta\}-arrestin. Mol Endocrinol 2009; 23:2060-74.

16. Zhang C, Roepke TA, Kelly MJ, Rønnekleiv OK. Kisspeptin depolarizes gonadotropin-releasing hormone neurons through activation of TRPC-like cationic channels. J Neurosci 2008; 28:4423-34.

17. Seminara SB, Dipietro MJ, Ramaswamy S, Crowley WF Jr, Plant TM. Continuous human metastin 45-54 infusion desensitizes $G$ protein-coupled receptor 54 -induced gonadotropin-releasing hormone release monitored indirectly in the juvenile male Rhesus monkey (Macaca mulatta): a finding with therapeutic implications. Endocrinology 2006; 147:2122-6.

18. Jayasena CN, Nijher GMK, Abbara A, et al. Twice-weekly administration of kisspeptin-54 for 8 weeks stimulates release of reproductive hormones in women with hypothalamic amenorrhea. Clin Pharmacol Ther 2010; 88:840-7.

19. Dumalska I, Wu M, Morozova E, et al. Excitatory effects of the pubertyinitiating peptide kisspeptin and group I metabotropic glutamate receptor agonists differentiate two distinct subpopulations of gonadotropin-releasing hormone neurons. J Neurosci 2008; 28:8003-13.

20. Pielecka-Fortuna J, Chu Z, Moenter SM. Kisspeptin acts directly and indirectly to increase gonadotropin-releasing hormone neuron activity and its effects are modulated by estradiol. Endocrinology 2008; 149:1979-86.

21. Caraty A, Smith JT, Lomet D, et al. Kisspeptin synchronizes preovulatory surges in cyclical ewes and causes ovulation in seasonally acyclic ewes. Endocrinology 2007; 148:5258-67.

22. Plant TM, Ramaswamy S, Dipietro MJ. Repetitive activation of hypothalamic G protein-coupled receptor 54 with intravenous pulses of kisspeptin in the juvenile monkey (Macaca mulatta) elicits a sustained train of gonadotropinreleasing hormone discharges. Endocrinology 2006; 147:1007-13.

23. Thompson EL, Murphy KG, Patterson M, et al. Chronic subcutaneous administration of kisspeptin-54 causes testicular degeneration in adult male rats. Am J Physiol Endocrinol Metab 2006; 291:E1074-82.

24. Roa J, Vigo E, García-Galiano D, et al. Desensitization of gonadotropin responses to kisspeptin in the female rat: analyses of $\mathrm{LH}$ and $\mathrm{FSH}$ secretion at different developmental and metabolic states. Am J Physiol Endocrinol Metab 2008; 294:E1088-96.

25. Rance NE, Krajewski SJ, Smith MA, Cholanian M, Dacks PA. Neurokinin B and the hypothalamic regulation of reproduction. Brain Res 2010; 1364:116-28.

26. Pinilla L, Aguilar E, Dieguez C, Millar RP, Tena-Sempere M. Kisspeptins and reproduction: physiological roles and regulatory mechanisms. Physiol Rev 2012; 92:1235-316.

27. Topaloglu AK, Reimann F, Guclu M, et al. TAC3 and TACR3 mutations in familial hypogonadotropic hypogonadism reveal a key role for Neurokinin B in the central control of reproduction. Nat Genet 2009; 41:354-8.

28. Yen SS, Quigley ME, Reid RL, Ropert JF, Cetel NS. Neuroendocrinology of opioid peptides and their role in the control of gonadotropin and prolactin secretion. Am J Obstet Gynecol 1985; 152:485-93.

29. Navarro VM, Castellano JM, McConkey SM, et al. Interactions between kisspeptin and neurokinin B in the control of $\mathrm{GnRH}$ secretion in the female rat. Am J Physiol Endocrinol Metab 2011; 300:E202-10.

30. Navarro VM, Gottsch ML, Chavkin C, et al. Regulation of gonadotropinreleasing hormone secretion by kisspeptin/dynorphin/neurokinin B neurons in the arcuate nucleus of the mouse. J Neurosci 2009; 29:11859-66.

31. García-Galiano D, van Ingen Schenau D, Leon S, et al. Kisspeptin signaling is indispensable for neurokinin B, but not glutamate, stimulation of gonadotropin secretion in mice. Endocrinology 2012; 153:316-28.

32. Ramaswamy S, Seminara SB, Plant TM. Evidence from the agonadal juvenile male rhesus monkey (Macaca mulatta) for the view that the action of neurokinin B to trigger gonadotropin-releasing hormone release is upstream from the kisspeptin receptor. Neuroendocrinology 2011; 94:237-45.

33. Goodman RL, Coolen LM, Anderson GM, et al. Evidence that dynorphin plays a major role in mediating progesterone negative feedback on gonadotropin-releasing hormone neurons in sheep. Endocrinology 2004; 145:2959-67.

34. Lehman MN, Coolen LM, Goodman RL. Minireview: kisspeptin/neurokinin B/dynorphin (KNDy) cells of the arcuate nucleus: a central node in the control of gonadotropin-releasing hormone secretion. Endocrinology 2010; 151:3479-89. 
35. Goodman RL, Lehman MN, Smith JT, et al. Kisspeptin neurons in the arcuate nucleus of the ewe express both dynorphin A and neurokinin B. Endocrinology 2007; 148:5752-60.

36. Hrabovszky E, Ciofi P, Vida B, et al. The kisspeptin system of the human hypothalamus: sexual dimorphism and relationship with gonadotropinreleasing hormone and neurokinin B neurons. Eur J Neurosci 2010; 31:1984-98.

37. Krajewski SJ, Anderson MJ, Iles-Shih L, et al. Morphologic evidence that neurokinin B modulates gonadotropin-releasing hormone secretion via neurokinin 3 receptors in the rat median eminence. J Comp Neurol 2005; 489:372-86.

38. Todman MG, Han SK, Herbison AE. Profiling neurotransmitter receptor expression in mouse gonadotropin-releasing hormone neurons using green fluorescent protein-promoter transgenics and microarrays. Neuroscience 2005; 132:703-12.

39. Amstalden M, Coolen LM, Hemmerle AM, et al. Neurokinin 3 recepto immunoreactivity in the septal region, preoptic area and hypothalamus of the female sheep: colocalisation in neurokinin B cells of the arcuate nucleus but not in gonadotrophin-releasing hormone neurones. J Neuroendocrinol 2010; 22:1-12.

40. Brailoiu GC, Dun SL, Ohsawa M, et al. KiSS-1 expression and metastin-like immunoreactivity in the rat brain. J Comp Neurol 2005; 481:314-29.

41. Adachi S, Yamada S, Takatsu Y, et al. Involvement of anteroventral periventricular metastin/kisspeptin neurons in estrogen positive feedback action on luteinizing hormone release in female rats. J Reprod Dev 2007, 53:367-78.

42. Clarkson J, d'Anglemont de Tassigny X, Colledge WH, Caraty A, Herbison AE. Distribution of kisspeptin neurones in the adult female mouse brain. J Neuroendocrinol 2009; 21:673-82.

43. Clarkson J, Herbison AE. Postnatal development of kisspeptin neurons in mouse hypothalamus; sexual dimorphism and projections to gonadotropinreleasing hormone neurons. Endocrinology 2006; 147:5817-25.

44. Smith JT, Cunningham MJ, Rissman EF, Clifton DK, Steiner RA. Regulation of Kiss 1 gene expression in the brain of the female mouse. Endocrinology 2005; 146:3686-92.

45. Smith JT, Dungan HM, Stoll EA, et al. Differential regulation of KiSS-1 mRNA expression by sex steroids in the brain of the male mouse. Endocrinology 2005; 146:2976-84.

46. Backholer K, Smith J, Clarke IJ. Melanocortins may stimulate reproduction by activating orexin neurons in the dorsomedial hypothalamus and kisspeptin neurons in the preoptic area of the ewe. Endocrinology 2009; 150:5488-97.

47. Backholer K, Smith JT, Rao A, et al. Kisspeptin cells in the ewe brain respond to leptin and communicate with neuropeptide $\mathrm{Y}$ and proopiomelanocortin cells. Endocrinology 2010; 151:2233-43.

48. Franceschini I, Lomet D, Cateau M, et al. Kisspeptin immunoreactive cells of the ovine preoptic area and arcuate nucleus co-express estrogen receptor alpha. Neurosci Lett 2006; 401:225-30.

49. Ramaswamy S, Guerriero KA, Gibbs RB, Plant TM. Structural interactions between kisspeptin and GnRH neurons in the mediobasal hypothalamus of the male rhesus monkey (Macaca mulatta) as revealed by double immunofluorescence and confocal microscopy. Endocrinology 2008 149:4387-95.

50. Roseweir AK, Kauffman AS, Smith JT, et al. Discovery of potent kisspeptin antagonists delineate physiological mechanisms of gonadotropin regulation. J Neurosci 2009; 29:3920-9.

51. Li XF, Kinsey-Jones JS, Cheng $\mathrm{Y}$, et al. Kisspeptin signalling in the hypothalamic arcuate nucleus regulates $\mathrm{GnRH}$ pulse generator frequency in the rat. PLoS One 2009; 4:e8334.

52. Navarro VM, Castellano JM, Fernández-Fernández R, et al. Developmental and hormonally regulated messenger ribonucleic acid expression of KiSS-1 and its putative receptor, GPR54, in rat hypothalamus and poten luteinizing hormone-releasing activity of KiSS-1 peptide. Endocrinology 2004; 145:4565-74.

53. Navarro VM, Castellano JM, Fernández-Fernández R, et al. Characterization of the potent luteinizing hormone-releasing activity of KiSS-1 peptide, the natural ligand of GPR54. Endocrinology 2005; 146:156-63.

54. Matsui H, Takatsu Y, Kumano S, Matsumoto H, Ohtaki T. Peripheral administration of metastin induces marked gonadotropin release and ovulation in the rat. Biochem Biophys Res Commun 2004; 320:383-8.

55. Patterson M, Murphy KG, Thompson EL, et al. Administration of kisspeptin-54 into discrete regions of the hypothalamus potently increases plasma luteinising hormone and testosterone in male adult rats. J Neuroendocrinol 2006; 18:349-54.

56. Pheng V, Uenoyama $\mathrm{Y}$, Homma $\mathrm{T}$, et al. Potencies of centrally- or peripherally-injected full-length kisspeptin or its C-terminal decapeptide on LH release in intact male rats. J Reprod Dev 2009; 55:378-82.

57. Tovar S, Vázquez MJ, Navarro VM, et al. Effects of single or repeated intravenous administration of kisspeptin upon dynamic LH secretion in conscious male rats. Endocrinology 2006; 147:2696-704.

58. Thompson EL, Patterson M, Murphy KG, et al. Central and peripheral administration of kisspeptin-10 stimulates the hypothalamic-pituitarygonadal axis. J Neuroendocrinol 2004; 16:850-8.

59. Dhillo WS, Chaudhri OB, Thompson EL, et al. Kisspeptin-54 stimulates gonadotropin release most potently during the preovulatory phase of the menstrual cycle in women. J Clin Endocrinol Metab 2007; 92:3958-66.

60. Gottsch ML, Cunningham MJ, Smith JT, et al. A role for kisspeptins in the regulation of gonadotropin secretion in the mouse. Endocrinology 2004; 145:4073-7.

61. Messager S. Kisspeptin and its receptor: new gatekeepers of puberty. J Neuroendocrinol 2005; 17:687-8.

62. Shahab M, Mastronardi C, Seminara SB, et al. Increased hypothalamic GPR54 signaling: a potential mechanism for initiation of puberty in primates. Proc Natl Acad Sci U S A 2005; 102:2129-34.

63. Navarro VM, Castellano JM, Fernández-Fernández R, et al. Effects of KiSS-1 peptide, the natural ligand of GPR54, on follicle-stimulating hormone secretion in the rat. Endocrinology 2005; 146:1689-97.

64. d'Anglemont de Tassigny X, Fagg LA, Dixon JP, et al. Hypogonadotropic hypogonadism in mice lacking a functional Kiss1 gene. Proc Natl Acad Sci U S A 2007; 104:10714-9.

65. George JT, Veldhuis JD, Roseweir AK, et al. Kisspeptin-10 is a poten stimulator of LH and increases pulse frequency in men. J Clin Endocrinol Metab 2011; 96:E1228-36.

66. McCann SM, Karanth S, Mastronardi CA, et al. Hypothalamic control of gonadotropin secretion. Prog Brain Res 2002; 141:151-64.

67. Chan YM, Butler JP, Pinnell NE, et al. Kisspeptin resets the hypothalamic GnRH clock in men. J Clin Endocrinol Metab 2011; 96:E908-15.

68. Burger LL, Dalkin AC, Aylor KW, Haisenleder DJ, Marshall JC. GnRH pulse frequency modulation of gonadotropin subunit gene transcription in normal gonadotropes-assessment by primary transcript assay provides evidence for roles of GnRH and follistatin. Endocrinology 2002; 143:3243-9.

69. de Kretser DM, Hedger MP, Loveland KL, Phillips DJ. Inhibins, activins and follistatin in reproduction. Hum Reprod Update 2002; 8:529-41.

70. Kauffman AS, Gottsch ML, Roa J, et al. Sexual differentiation of Kiss1 gene expression in the brain of the rat. Endocrinology 2007; 148:1774-83.

71. Smith JT, Clay CM, Caraty A, Clarke IJ. KiSS-1 messenger ribonucleic acid expression in the hypothalamus of the ewe is regulated by sex steroids and season. Endocrinology 2007; 148:1150-7.

72. Rometo AM, Krajewski SJ, Voytko ML, Rance NE. Hypertrophy and increased kisspeptin gene expression in the hypothalamic infundibular nucleus of postmenopausal women and ovariectomized monkeys. J Clin Endocrinol Metab 2007; 92:2744-50.

73. Shibata M, Friedman RL, Ramaswamy S, Plant TM. Evidence that down regulation of hypothalamic KiSS-1 expression is involved in the negative feedback action of testosterone to regulate luteinising hormone secretion in the adult male rhesus monkey (Macaca mulatta). J Neuroendocrinol 2007; 19:432-8

74. Colledge WH. Kisspeptins and GnRH neuronal signalling. Trends Endocrinol Metab 2009; 20:115-21.

75. Herbison AE. Estrogen positive feedback to gonadotropin-releasing hormone $(\mathrm{GnRH})$ neurons in the rodent: the case for the rostral periventricular area of the third ventricle (RP3V). Brain Res Rev 2008; 57:277-87.

76. Clarkson J, Herbison AE. Oestrogen, kisspeptin, GPR54 and the preovulatory luteinising hormone surge. J Neuroendocrinol 2009; 21:305-11.

77. Christian CA, Moenter SM. The neurobiology of preovulatory and estradiolinduced gonadotropin-releasing hormone surges. Endocr Rev 2010; 31:544-77.

78. Wintermantel TM, Campbell RE, Porteous R, et al. Definition of estrogen receptor pathway critical for estrogen positive feedback to gonadotropinreleasing hormone neurons and fertility. Neuron 2006; 52:271-80.

79. Simerly RB. Wired for reproduction: organization and development of sexually dimorphic circuits in the mammalian forebrain. Annu Rev Neurosci 2002; 25:507-36.

80. Karsch FJ, Foster DL. Sexual differentiation of the mechanism controlling the preovulatory discharge of luteinizing hormone in sheep. Endocrinology $1975 ; 97: 373-9$

81. Corbier P. Sexual differentiation of positive feedback: effect of hour of castration at birth on estradiol-induced luteinizing hormone secretion in immature male rats. Endocrinology 1985; 116:142-7. 
82. Gogan F, Beattie IA, Hery M, Laplante E, Kordon D. Effect of neonata administration of steroids or gonadectomy upon oestradiol-induced luteinizing hormone release in rats of both sexes. J Endocrinol 1980; 85:69-74.

83. Hoffman GE, Le WW, Schulterbrandt T, Legan SJ. Estrogen and progesterone do not activate Fos in AVPV or LHRH neurons in male rats. Brain Res 2005; 1054:116-24.

84. Navarro VM, Sánchez-Garrido MA, Castellano JM, et al. Persisten impairment of hypothalamic KiSS-1 system after exposures to estrogenic compounds at critical periods of brain sex differentiation. Endocrinology 2009; 150:2359-67.

85. Gore AC, Walker DM, Zama AM, Armenti AE, Uzumcu M. Early life exposure to endocrine-disrupting chemicals causes lifelong molecula reprogramming of the hypothalamus and premature reproductive aging Mol Endocrinol 2011; 25:2157-68.

86. Homma T, Sakakibara M, Yamada S, et al. Significance of neonata testicular sex steroids to defeminize anteroventral periventricula kisspeptin neurons and the GnRH/LH surge system in male rats. Biol Reprod 2009; 81:1216-25.

87. Navarro VM, Gottsch ML, Wu M, et al. Regulation of NKB pathways and their roles in the control of Kiss1 neurons in the arcuate nucleus of the male mouse. Endocrinology 2011; 152:4265-75.

88. Herbison AE, Pape JR. New evidence for estrogen receptors in gonadotropinreleasing hormone neurons. Front Neuroendocrinol 2001; 22:292-308.

89. Kim W, Jessen HM, Auger AP, Terasawa E. Postmenopausal increase in KiSS-1, GPR54, and luteinizing hormone releasing hormone (LHRH-1) mRNA in the basal hypothalamus of female rhesus monkeys. Peptides 2009; 30:103-10.

90. Tomikawa J, Homma T, Tajima S, et al. Molecular characterization and estrogen regulation of hypothalamic KISS1 gene in the pig. Biol Reprod 2010; 82:313-9.

91. Chan YM, Broder-Fingert S, Wong KM, Seminara SB. Kisspeptin/Gpr54independent gonadotrophin-releasing hormone activity in Kiss1 and Gpr54 mutant mice. J Neuroendocrinol 2009; 21:1015-23.

92. Dungan HM, Gottsch ML, Zeng H, et al. The role of kisspeptin-GPR54 signaling in the tonic regulation and surge release of gonadotropinreleasing hormone/luteinizing hormone. J Neurosci 2007; 27:12088-95

93. Roa J, Vigo E, Castellano JM, et al. Opposite roles of estrogen receptor (ER)-alpha and ERbeta in the modulation of luteinizing hormone responses to kisspeptin in the female rat: implications for the generation of the preovulatory surge. Endocrinology 2008; 149:1627-37.

94. Couse JF, Korach KS. Estrogen receptor null mice: what have we learned and where will they lead us? Endocr Rev 1999; 20:358-417.

95. Smith JT, Popa SM, Clifton DK, Hoffman GE, Steiner RA. Kiss1 neurons in the forebrain as central processors for generating the preovulatory luteinizing hormone surge. J Neurosci 2006; 26:6687-94.

96. Goodman RL. The site of the positive feedback action of estradiol in the rat. Endocrinology 1978; 102:151-9.

97. Kinoshita $\mathrm{M}$, Tsukamura $\mathrm{H}$, Adachi $\mathrm{S}$, et al. Involvement of central metastin in the regulation of preovulatory luteinizing hormone surge and estrous cyclicity in female rats. Endocrinology 2005; 146:4431-6.

98. Roa J, Vigo E, Castellano JM, et al. Hypothalamic expression of KiSS-1 system and gonadotropin-releasing effects of kisspeptin in different reproductive states of the female Rat. Endocrinology 2006; 147:2864-78.

99. Dhillo WS, Chaudhri OB, Patterson M, et al. Kisspeptin-54 stimulates the hypothalamic-pituitary gonadal axis in human males. J Clin Endocrinol Metab 2005; 90:6609-15

100. Pineda R, Garcia-Galiano D, Roseweir A, et al. Critical roles of kisspeptins in female puberty and preovulatory gonadotropin surges as revealed by a novel antagonist. Endocrinology 2010; 151:722-30.

101. Smith JT, Li Q, Yap KS, et al. Kisspeptin is essential for the full preovulatory $\mathrm{LH}$ surge and stimulates $\mathrm{GnRH}$ release from the isolated ovine median eminence. Endocrinology 2011; 152:1001-12.

102. Le WW, Berghorn KA, Rassnick S, Hoffman GE. Periventricular preoptic area neurons coactivated with luteinizing hormone (LH)-releasing hormone $(\mathrm{LHRH})$ neurons at the time of the LH surge are LHRH afferents. Endocrinology 1999; 140:510-9.

103. Terasawa E, Wiegand SJ, Bridson WE. A role for medial preoptic nucleus on afternoon of proestrus in female rats. Am J Physiol 1980; 238:E533-9.

104. Wiegand SJ, Terasawa E. Discrete lesions reveal functional heterogeneity of suprachiasmatic structures in regulation of gonadotropin secretion in the female rat. Neuroendocrinology 1982; 34:395-404.

105. Wiegand SJ, Terasawa E, Bridson WE. Persistent estrus and blockade of progesterone-induced $\mathrm{LH}$ release follows lesions which do not damage the suprachiasmatic nucleus. Endocrinology 1978; 102:1645-8.
106. Seminara SB, Messager S, Chatzidaki EE, et al. The GPR54 gene as a regulator of puberty. N Engl J Med 2003; 349:1614-27.

107. Funes S, Hedrick JA, Vassileva G, et al. The KiSS-1 receptor GPR54 is essential for the development of the murine reproductive system. Biochem Biophys Res Commun 2003; 312:1357-63.

108. de Roux N, Genin E, Carel JC, et al. Hypogonadotropic hypogonadism due to loss of function of the KiSS1-derived peptide receptor GPR54. Proc Natl Acad Sci U S A 2003; 100:10972-6.

109. Semple RK, Achermann JC, Ellery J, et al. Two novel missense mutations in g protein-coupled receptor 54 in a patient with hypogonadotropic hypogonadism. J Clin Endocrinol Metab 2005; 90:1849-55.

110. Kauffman AS, Park JH, McPhie-Lalmansingh AA, et al. The kisspeptin receptor GPR54 is required for sexual differentiation of the brain and behavior. J Neurosci 2007; 27:8826-35.

111. Lapatto R, Pallais JC, Zhang D, et al. Kiss1-/- mice exhibit more variable hypogonadism than Gpr54-/- mice. Endocrinology 2007; 148:4927-36.

112. Herbison AE, de Tassigny Xd, Doran J, Colledge WH. Distribution and postnatal development of Gpr54 gene expression in mouse brain and gonadotropin-releasing hormone neurons. Endocrinology 2010; 151:312-21.

113. Gill JC, Wang O, Kakar S, et al. Reproductive hormone-dependent and-independent contributions to developmental changes in kisspeptin in GnRH-deficient hypogonadal mice. PLoS One 2010; 5:e11911.

114. lijima N, Takumi K, Sawai N, Ozawa H. An immunohistochemical study on the expressional dynamics of kisspeptin neurons relevant to GnRH neurons using a newly developed anti-kisspeptin antibody. J Mol Neurosci 2011; 43:146-54

115. Takase K, Uenoyama Y, Inoue N, et al. Possible role of oestrogen in pubertal increase of Kiss1/kisspeptin expression in discrete hypothalamic areas of female rats. J Neuroendocrinol 2009; 21:527-37.

116. Takumi K, lijima N, Ozawa H. Developmental changes in the expression of kisspeptin mRNA in rat hypothalamus. J Mol Neurosci 2011; 43:138-45.

117. Bentsen AH, Ansel L, Simonneaux V, et al. Maturation of kisspeptinergic neurons coincides with puberty onset in male rats. Peptides 2010; 31:275-83.

118. Terasawa E, Kurian JR, Guerriero KA, et al. Recent discoveries on the control of gonadotrophin-releasing hormone neurones in nonhuman primates. J Neuroendocrinol 2010; 22:630-8

119. Ojeda SR, Lomniczi A, Mastronardi C, et al. Minireview: the neuroendocrine regulation of puberty: is the time ripe for a systems biology approach? Endocrinology 2006; 147:1166-74.

120. Ojeda SR, Lomniczi A, Sandau U, Matagne V. New concepts on the control of the onset of puberty. Endocr Dev 2010; 17:44-51.

121. Navarro VM, Fernández-Fernández R, Castellano JM, et al. Advanced vaginal opening and precocious activation of the reproductive axis by KiSS-1 peptide, the endogenous ligand of GPR54. J Physiol 2004; 561(Pt 2):379-86.

122. Guerriero KA, Keen KL, Millar RP, Terasawa E. Developmental changes in $\mathrm{GnRH}$ release in response to kisspeptin agonist and antagonist in female rhesus monkeys (Macaca mulatta): implication for the mechanism of puberty. Endocrinology 2012; 153:825-36

123. Breuillaud L, Halfon O, Magistretti PJ, Pralong FP, Cardinaux JR. Mouse fertility is not dependent on the CREB coactivator Crtc1. Nat Med 2009; 15:989-90; author reply 991.

124. Castellano JM, Navarro VM, Fernández-Fernández R, et al. Changes in hypothalamic KiSS-1 system and restoration of pubertal activation of the reproductive axis by kisspeptin in undernutrition. Endocrinology 2005; 146:3917-25.

125. Castellano JM, Navarro VM, Fernández-Fernández R, et al. Expression of hypothalamic KiSS-1 system and rescue of defective gonadotropic responses by kisspeptin in streptozotocin-induced diabetic male rats. Diabetes 2006; 55:2602-10

126. Castellano JM, Navarro VM, Roa J, et al. Alterations in hypothalamic KiSS-1 system in experimental diabetes: early changes and functional consequences. Endocrinology 2009; 150:784-94

127. Brown RE, Imran SA, Ur E, Wilkinson M. KiSS-1 mRNA in adipose tissue is regulated by sex hormones and food intake. Mol Cell Endocrinol 2008; 281:64-72.

128. Matsuzaki T, Iwasa T, Kinouchi R, et al. Fasting reduces the kiss 1 mRNA levels in the caudal hypothalamus of gonadally intact adult female rats. Endocr J 2011; 58:1003-12.

129. Luque RM, Kineman RD, Tena-Sempere M. Regulation of hypothalamic expression of KiSS-1 and GPR54 genes by metabolic factors: analyses using mouse models and a cell line. Endocrinology 2007; 148:4601-11. 
130. Roa J, Garcia-Galiano D, Varela L, et al. The mammalian target of rapamycin as novel central regulator of puberty onset via modulation of hypothalamic Kiss1 system. Endocrinology 2009; 150:5016-26.

131. Kalamatianos T, Grimshaw SE, Poorun R, Hahn JD, Coen CW. Fasting reduces KiSS-1 expression in the anteroventral periventricular nucleus (AVPV): effects of fasting on the expression of KiSS-1 and neuropeptide $Y$ in the AVPV or arcuate nucleus of female rats. J Neuroendocrinol 2008; 20:1089-97.

132. Quennell JH, Mulligan AC, Tups A, et al. Leptin indirectly regulates gonadotropin-releasing hormone neuronal function. Endocrinology 2009; 150:2805-12.

133. Smith JT, Acohido BV, Clifton DK, Steiner RA. KiSS-1 neurones are direct targets for leptin in the ob/ob mouse. J Neuroendocrinol 2006 18:298-303.

134. Cravo RM, Margatho LO, Osborne-Lawrence S, et al. Characterization of Kiss1 neurons using transgenic mouse models. Neuroscience 2011 173:37-56.

135. Quennell JH, Howell CS, Roa J, et al. Leptin deficiency and dietinduced obesity reduce hypothalamic kisspeptin expression in mice. Endocrinology 2011; 152:1541-50.

136. Morelli A, Marini M, Mancina R, et al. Sex steroids and leptin regulate the "first Kiss" (KiSS 1/G-protein-coupled receptor 54 system) in human gonadotropin-releasing-hormone-secreting neuroblasts. J Sex Med 2008, 5:1097-113.

137. Qiu J, Fang Y, Bosch MA, Rønnekleiv OK, Kelly MJ. Guinea pig kisspeptin neurons are depolarized by leptin via activation of TRPC channels. Endocrinology 2011; 152:1503-14.

138. Lee JH, Miele ME, Hicks DJ, et al. KiSS-1, a novel human malignant melanoma metastasis-suppressor gene. J Natl Cancer Inst 1996; 88:1731-7.

139. Kauffman EC, Robinson VL, Stadler WM, Sokoloff $\mathrm{MH}$ Rinker-Schaeffer CW. Metastasis suppression: the evolving role of metastasis suppressor genes for regulating cancer cell growth at the secondary site. J Urol 2003; 169:1122-33

140. Prabhu VV, Sakthivel KM, Guruvayoorappan C. Kisspeptins (KiSS-1): essential players in suppressing tumor metastasis. Asian Pac J Cancer Prev 2013; 14:6215-20.

141. Babwah AV, Pampillo M, Min L, Kaiser UB, Bhattacharya M. Singlecell analyses reveal that KISS1R-expressing cells undergo sustained kisspeptin-induced signaling that is dependent upon an influx of extracellular Ca2+. Endocrinology 2012; 153:5875-87.

142. Shirasaki F, Takata M, Hatta N, Takehara K. Loss of expression of the metastasis suppressor gene KiSS1 during melanoma progression and its association with LOH of chromosome 6q16.3-q23. Cancer Res 2001; 61:7422-5.

143. Sanchez-Carbayo M, Capodieci P, Cordon-Cardo C. Tumor suppressor role of KiSS-1 in bladder cancer: loss of KiSS-1 expression is associated with bladder cancer progression and clinical outcome. Am J Pathol 2003; 162:609-17.

144. Ikeguchi M, Yamaguchi K, Kaibara N. Clinical significance of the loss of KiSS-1 and orphan G-protein-coupled receptor (hOT7T175) gene expression in esophageal squamous cell carcinoma. Clin Cancer Res 2004; 10:1379-83.

145. Dhar DK, Naora H, Kubota H, et al. Downregulation of KiSS-1 expression is responsible for tumor invasion and worse prognosis in gastric carcinoma. Int J Cancer 2004; 111:868-72.

146. Ikeguchi M, Hirooka Y, Kaibara N. Quantitative reverse transcriptase polymerase chain reaction analysis for KiSS-1 and orphan G-proteincoupled receptor (hOT7T175) gene expression in hepatocellular carcinoma. J Cancer Res Clin Oncol 2003; 129:531-5.

147. Olbrich T, Ziegler E, Türk G, et al. Kisspeptin-10 inhibits bone-directed migration of GPR54-positive breast cancer cells: Evidence for a dosewindow effect. Gynecol Oncol 2010; 119:571-8.

148. Drakakis P, Loutradis D, Beloukas A, et al. Early hCG addition to rFSH for ovarian stimulation in IVF provides better results and the cDNA copies of the hCG receptor may be an indicator of successful stimulation. Reprod Biol Endocrinol 2009; 7:110.

149. Durnerin $\mathrm{Cl}$, Erb K, Fleming R, et al. Effects of recombinant $\mathrm{LH}$ treatment on folliculogenesis and responsiveness to FSH stimulation. Hum Reprod 2008; 23:421-6. 